\title{
STUDI KOMPARATIF DISTRIBUSI PENDAPATAN MASYARAKAT SEKITAR TAMBANG SEBELUM DAN SESUDAH MENDAPATKAN PROGRAM CORPORATE SOCIAL RESPONSIBILITY DI KABUPATEN BERAU
}

\author{
La Ode Ilyas \\ Fakultas Ekonomi Universitas Mulawarman \\ E-mail/No.Hp: perpusmsi.unmul@gmail.com/-
}

\begin{abstract}
Comparative study of the distribution of income communities around the mine before and after the Corporate Social Responsibility program in Berau is a study that aims to compare income communities around the mine before and after receiving the Corporate Social Responsibility (CSR) in Berau well as knowing the distribution of income communities. Based methods, this kind of research, including survey research combined with evaluation studies, because these studies can be conducted on large populations and small, and the data is the data sample studied samples taken from the population. In this study will be found relative events and distribution as well as the relationships between variables. Researchers can conclude that CSR programs are very influential on increasing revenue where $t>t$ table then Ho is rejected and Ha accepted. Then it can be said that there are differences in income communities around the mine before and after getting the CSR program in Berau.
\end{abstract}

Keywords; Distribution of Income, Stakeholders, CSR

\begin{abstract}
Abstrak
Pembahasan komparatip dari distribusi dari komunitas pendapatan di sekitar milikku sebelum dan setelah Kemasyarakatan Perusahaan tanggungjawab program di Berau adalah satu pembahasan arah itu untuk membandingkan komunitas pendapatan di sekitar milikku sebelum dan setelah mendapat Kemasyarakatan Perusahaan tanggungjawab( CSR) di Berau baik sebagai pengetahu distribusi dari komunitas pendapatan. Mendasari cara, ini semacam penelitian, meliputi penelitian survei berkombinasi dengan pembahasan evaluasi, karena pembahasan ini dapat dikendali pada populasi besar dan kekecilan, dan data adalah contoh data mempelajari contoh mengambil dari populasi. Di pembahasan ini akan ditemukan peristiwa relatif dan distribusi seperti halnya hubungan di antara variabel. Peneliti dapat menyimpulkan bahwa program CSR adalah sangat berpengaruh pada pendapatan peningkatan dimana $t>t$ tabel maka Ho ditolak dan Ha menerima. Kemudian ini dapat disebutkan yang di situ adalah perbedaan di komunitas pendapatan di sekitar milikku sebelum dan setelah memperoleh CSR program di Berau.
\end{abstract}

Kata Kunci; Distribusi dari Pendapatan, Pemegang taruhan, CSR 


\section{PENDAHULUAN}

Tingkat pendapatan kerap digunakan sebagai indikator tingkat keberhasilan pembangunan ekonomi suatu komunitas. Namun bila dilihat lebih jauh peningkatan pendapatan tersebut belum menjamin perbaikan kesejahteraan anggota masyarakat luas karena tingkat pendapatan yang bervariasi antara rumah tangga sesuai dengan tingkat penguasaan sumber daya dan kemampuan mengelolanya. Dengan perkataan lain bahwa peningkatan pendapatan suatu komunitas tidak selalu diikuti perbaikan distribusi diantara anggotanya. Sumber-sumber pendapatan suatu komunitaspun bukan hanya akibat peran pemerintah namun peran pihak ketiga dalam hal ini para pelaku usaha/ perusahaan bisa menjadi stimulus peningkatan pendapatan pada komunitas.

Perusahaan sebagai sistem, dalam keberlanjutan dan keseimbangannya tidak bisa berdiri sendiri. Eksistensi suatu perusahaan tidak bisa dipisahkan dengan masyarakat sebagai lingkungan eksternalnya. Ada hubungan resiprokal (timbal balik) antara perusahaan dengan masyarakat.
Perusahaan dan masyarakat adalah pasangan hidup yang saling memberi dan membutuhkan. Perusahaan selain mengejar keuntungan ekonomi untuk kesejahteraan dirinya, juga memerlukan alam untuk sumber daya olahannya dan stakeholders lain untuk mencapai tujuannya. Dengan menggunakan pendekatan tanggung jawab sosial perusahaan, perusahaan tidak hanya mendapatkan keuntungan ekonomi, tetapi juga keuntungan secara sosial.

Dalam perjalanan usahanya, beberapa perusahaan telah menjalankan suatu program Corporate Social Responsibility (CSR) yaitu suatu tindakan atau konsep yang dilakukan oleh perusahaan (sesuai kemampuan perusahaan tersebut) sebagai bentuk tanggungjawab sosial/ lingkungan sekitar tempat perusahaan itu berada. Contoh bentuk tanggungjawab itu bermacam-macam, mulai dari melakukan kegiatan yang dapat meningkatkan kesejahteraan masyarakat dan perbaikan lingkungan, pemberian beasiswa untuk anak tidak mampu, pemberian 
dana untuk pemeliharaan fasilitas umum, sumbangan untuk desa/fasilitas masyarakat yang bersifat sosial dan berguna untuk masyarakat banyak, khususnya masyarakat yang berada di sekitar perusahaan tersebut berada. CSR merupakan fenomena strategi perusahaan yang mengakomodasi kebutuhan dan kepentingan stakeholdernya. CSR timbul sejak kesadaran akan sustainability perusahaan jangka panjang lebih penting daripada sekedar profitability.

CSR memegang peranan penting dalam keberlangsungan operasional perusahaan. Beberapa contoh kasus Perusahaan yang memiliki masalah dengan tanggung jawab perusahaan lingkungan yang tidak tepat antara lain kasus pemblokiran jalan oleh warga di Papua terhadap kendaraan-kendaraan milik Freeport, kasus gugatan warga terhadap PT.Newmont di Buyat dan yang mengalami konflik dengan masyarakat sekitar sehingga operasi pabrik sempat dihentikan, menggambarkan kekecewaan warga terhadap ketidakpekaan perusahaanperusahaan yang beroperasi di wilayah-wilayah tersebut.

Perusahaan yang bergerak di bidang pengelolaan sumber daya alam (batu bara) di Kabupaten Berau, PT. Berau Coal mengartikan program CSR bukan hanya program yang bersifat philantropis. Program CSR dimaknai sebagai indikator mutlak dalam menjalankan operasional pengelolaan sumberdaya alam di Kabupaten Berau. Namun disadari bahwa program CSR tersebut tidak dapat diaplikasikan keseluruh masyarakat se Kabupaten Berau akan tetapi hanya terbatas pada kampung / desa yang terdekat dengan aktifitas perusahaan. Makna implementasi tanggung jawab sosial perusahaan sebagai suatu bentuk tanggung jawab perusahaan untuk mempertemukan berbagai kepentingan yang terkait dengan aktivitas perusahaan, tidak saja bagi kepentingan internal, tetapi juga kepentingan eksternal (sesuai dengan pendekatan stakeholders).

Majunya tingkat pendidikan, kesehatan yang berkualitas, terbukanya berbagai jenis lapangan kerja baru, berbagai bentuk program mitra kerja perusahan, dan juga berkembangnya sektor informal, 
adalah menjadi hal penting bagi indikator keberhasilan program perbaikan kehidupan perekonomian masyarakat lingkar tambang. Pembangunan sarana fisik bagi lingkungan masyarakat, sumbangan di bidang pendidikan dan kesehatan masyarakat, secara tidak langsung juga telah memberi pengaruh peningkatan kualitas SDM dan potensi ekonomi masyarakat.

Teori Pendapatan Menurut Mubyarto (1989) bahwa pendapatan merupakan penerimaan yang dikurangi dengan biaya-biaya yang dikeluarkan. Pendapatan seseorang pada dasarnya tergantung dari pekerjaan di bidang jasa atas produksi serta waktu, jam kerja yang dicurahkan, tingkat pendapatan perjam yang diterima, serta jenis pekerjaan yang dilakukan. Tingkat pendapatan perjam yang diterima dipengaruhi oleh pendidikan, keterampilan serta sumber-sumber non tenaga kerja yang dikuasai seperti tanah, modal, dan terknologi. Definisi pendapatan juga dikemukakan oleh Weygandi (1986) dalam Nurmanaf (1999) yang mengatakan bahwa pendapatan (revenue) merupakan aliran masuk kas atau setara kasnya yang terjadi akibat adanya penjualan barang atau jasa yang dihasilkan.

Corporate Social

Responsibility (CSR). Wibisono (2007) mendefinisikan CSR sebagai tanggung jawab perusahaan kepada pemangku kepentingan untuk berlaku etis, meminimalkan dampak negatif dan memaksimalkan dampak positif yang mencakup aspek ekonomi sosial dan lingkungan (triple bottom line) dalam rangka mencapai tujuan pembangunan berkelanjutan. Sementara Nursahid (2006) mendefinisikan CSR sebagai tanggung jawab moral suatu organisasi bisnis terhadap kelompok yang menjadi stakeholder-nya yang terkena pengaruh baik secara langsung ataupun tidak langsung dari operasi perusahaan.

Pengembangan Masyarakat. Dalam melaksanakan suatu program pengembangan masyarakat terdapat berbagai macam strategi pengembangan masyarakat. Chin dan Benne (1961) dalam Nasdian (2006) memperkenalkan tiga strategi yang dapat dijadikan strategi pengembangan masyarakat, yaitu 
rational-empirical, normativereeducative, dan power-coersive.

Hasil Penelitian yang dilakukan oleh Nurmanaf (2005) dari Pusat Analisis Sosial Ekonomi dan Kebijakan Pertanian, Badan Litbang Departemen Pertanian Bogor berjudul Peningkatan Pendapatan Masyarakat Pedesaan dalam hubungannya dengan distribusi antar rumah tangga. Penelitian ini bertujuan untuk menguji keterkaitan dan hubungan antara tingkat ketidakmerataan distribusi pendapatan antar rumah tangga dengan pendapatan perkapita di pedesaan. Atau, berapa besar pengaruh peningkatan pendapatan terhadap tingkat ketimpangan distribusi pendapatan. Lebih makro dapat dikatakan berapa besar keberhasilan pembangunan terhadap perbaikan distribusi pendapatan sebagai proksi kesejahteraan masyarakat. Disamping itu, keterkaitan hubungan tersebut dengan sumber- sumber pendapatan dan identifikasi beberapa faktor terhadap tingkat ketidakmerataan distribusi pendapatan juga merupakan bagian dalam diskusi.

Hasil penelitian Prapti
(2006), yang berjudul Keterkaitan

Pertumbuhan Ekonomi dan Distribusi Pendapatan. Penelitian ini bertujuan untuk menganalisis keterkaitan pertumbuhan ekonomi dan distribusi pendapatan di 35 Kabupaten / Kota Jawa Tengah dengan mengkorelasikannya pada hipotesis "U" terbalik yang diajukan Simon Kuznets. Menurut Kuznets bahwa pada awal pembangunan, pertumbuhan ekonomi yang tinggi akan diikuti dengan ketimpangan pendapatan antar penduduk yang tinggi pula. Hasil penelitian menunjukkan bahwa meskipun tingkat kesenjangan pendapatan penduduk di 35 Kabupaten / Kota Jawa Tengah relatif rendah (masih di bawah 0,3), namun keterkaitan bahwa meningkatnya pertumbuhan ekonomi akan diikuti dengan meningkatnya tingkat kesenjangan pendapatan penduduk terjadi di sebagian besar Kabupaten / Kota di Jawa Tengah.

Hasil penelitian Rachman dan Supriyati (2001), Puslitbang Sosial Ekonomi Pertanian Bogor yang berjudul Struktur dan Distribusi Pendapatan Rumah Tangga Petani 
Lahan Sawah di Jawa dan luar Jawa.

Penelitian ini bertujuan untuk mempelajari struktur dan distribusi pendapatan rumah tangga petani lahan sawah di Jawa dan luar Jawa, sehingga ketimpangan maupun pemerataan distribusi pendapatan dapat dijelaskan dan terefleksikan pada ketimpangan maupun pemerataan distribusi penguasaan lahan ataupun penggarapan lahan pertanian. Ada beberapa metode penelitian yang digunakan dalam penelitian ini. Untuk mengkaji struktur pendapatan rumah tangga, analisis dilakukan dengan metoda diskriptif melalui metoda akunting, dalam hal ini pendapatan total rumah tangga merupakan penjumlahan pendapatan dari sektor pertanian dan pendapatan non pertanian. Analisa ragam sumber pendapatan dilakukan dengan menelaah sebaran rumah tangga menurut status rumah tangga dan jumlah sumber pendapatan. Analisa struktur dan distribusi pendapatan dilakukan untuk agregasi wilayah Jawa dan luar Jawa.

\section{METODE PENELITIAN}

Operasionalisasi penelitian ini melalui proses atau langkahlangkah yang bersifat ilmiah dan logis. Oleh sebab itu, agar penelitian ini mengacu pada pemecahan masalah dan tujuan yang ingin dicapai serta pengujian hipotesis, berikut ini operasionalisasi parameter penelitian didefinisikan sebagai berikut:

Pendapatan yang dimaksud dalam penelitian adalah seluruh penerimaan masyarakat sekitar tambang di Kabupaten Berau baik berupa uang atau barang dari hasil usaha atau produksi rumah tangga baik pendapatan formal, informal maupun sub sistem. Pendapatan formal adalah penghasilan yang di peroleh melalui pekerjaan pokok dan pendapatan sub sistem adalah penghasilan yang di peroleh dari faktor produksi yang di nilai dengan uang.

Distribusi pendapatan dalam penelitian ini adalah distribusi pendapatan relatif antar penduduk masyarakat sekitar tambang di Kabupaten Berau berdasarkan golongan pendapatan sebelum dan 
setelah mendapat program

pendapatan masyarakat sekitar

Corporate Social Responsibility.

Corporate

Social

Responsibility yang selanjutnya disingkat CSR dalam penelitian ini adalah program yang menjadi komitmen tanggung jawab sosial perusahaan PT Berau Coal melalui kontribusinya kepada masyarakat sekitarnya dalam upaya pengembangan ekonomi dan sosial, baik dalam bentuk fisik maupun nonfisik atau dalam bentuk finansial dan manajemen pembinaan.

Indeks Gini merupakan koefisien yang didasarkan pada “kurva Lorenz", yaitu sebuah kurva pendapatan kumulatif yang membandingkan distribusi dari suatu variable tertentu (misalnya pendapatan) dengan distribusi uniform (seragam) yang mewakili persentase kumulatif penduduk. Koefisien gini didefinisikan sebagai $\mathrm{A} /(\mathrm{A}+\mathrm{B})$, jika $\mathrm{A}=0$ koefisien gini bernilai 0 yang berarti pemerataan sempurnah, jika $B=0$ Koefisien gini akan bernilai 1 yang berarti ketimpangan sempurna. Satuan dari variabel GINI adalah rasio yang menggambarkan distribusi tambang.

Dalam melakukan analisis dan interprestasi data serta menjawab hipotesis yang telah dirumuskan dalam penelitian ini, dipergunakan teknik analisis sebagai berikut :

Analisis kualitatif merupakan analisis yang bersifat subyektif dengan mendasarkan pada pandangan serta pemikiran secara teoritis dengan memberikan gambaran mengenai kesesuaian fakta penelitian dengan teori. Analisis yang diwujudkan dalam bentuk perhitungan angka - angka berdasarkan atas data yang terkumpul.

\section{PEMBAHASAN}

Untuk dapat menjawab permasalahan yang telah dikemukakan dan sekaligus membuktikan kebenaran hipotesis "adanya perbedaan yang signifikan distribusi pendapatan masyarakat sekitar tambang sebelum dan sesudah mendapatkan program CSR serta bagaimana distribusi pendapatan pada masyarakat sekitar tambang" sebagaimana yang telah diajukan dimuka maka perlu 
dilakukan beberapa analisis data. Adapun data yang akan dianalisis adalah rata-rata pendapatan masyarakat sekitar tambang sebelum dan sesudah yang mendapatkan program CSR, analisis komparasi pendapatan masyarakat sekitar tambang sebelum dan sesudah yang mendapatkan program CSR serta distribusi pendapatan masyarakat sekitar tambang sebelum dan sesudah yang mendapatkan program CSR.

Dari data hasil penelitian dapat dianalisis pendapatan rata-rata masyarakat sekitar tambang sebelum dan sesudah adanya program corporate sosial responsibility di Kabupaten Berau. Pendekatan jumlah sampel data pendapatan masyarakat sekitar tambang yang digunakan berdasarkan rumus Slovin. Perhitungan mean data tunggal dengan cara menunjukkan semua nilai data dibagi banyak data yang dijabarkan dengan rumus :

$\bar{X}=\frac{\sum x_{i}}{n}$

Dimana :

$\bar{X}=$ Mean, $\sum X_{i}=$ Jumlah tiap data $\mathrm{N}=$ Jumlah data

Data hasil Pendapatan masyarakat sekitar tambang sebelum dan sesudah mendapatkan Program CSR di Kabupaten Berau, data diolah menggunakan Uji $t$ Paired dengan SPSS.

Uji Hipotesis:

Ho : Tidak ada perbedaan pendapatan masyarakat sekitar tambang sebelum dan sesudah mendapatkan program CSR dikabupaten Berau. Ha : ada perbedaan pendapatan masyarakat sekitar tambang sebelum dan sesudah mendapatkan program CSR di Kabupaten Berau.

Data hasil Pendapatan masyarakat sekitar tambang sebelum dan sesudah mendapatkan Program CSR di Kabupaten Berau, data diolah menggunakan Uji $t$ Paired dengan SPSS.

Uji Hipotesis: Ho : Tidak ada perbedaan pendapatan masyarakat sekitar tambang sebelum dan sesudah mendapatkan program CSR di Kabupaten Berau. Ha : ada perbedaan pendapatan masyarakat sekitar tambang sebelum dan sesudah mendapatkan program CSR di Kabupaten Berau.

$$
\text { Kampung Tasuk Uji }
$$

Hipotesis: Ho : Tidak ada perbedaan pendapatan masyarakat sekitar 
tambang sebelum dan sesudah mendapatkan program CSR di Kabupaten Berau. Ha : ada perbedaan pendapatan masyarakat sekitar tambang sebelum dan sesudah mendapatkan program CSR di Kabupaten Berau. Kampung Birang Ho : Tidak ada perbedaan pendapatan masyarakat sekitar tambang sebelum dan sesudah mendapatkan program CSR di Kabupaten Berau. Ha : ada perbedaan pendapatan masyarakat sekitar tambang sebelum dan sesudah mendapatkan program CSR di Kabupaten Berau.Kampung Pagat Bukur Uji Hipotesis Ho : Tidak ada perbedaan pendapatan masyarakat sekitar tambang sebelum dan sesudah mendapatkan program CSR di Kabupaten Berau. Ha : ada perbedaan pendapatan masyarakat sekitar tambang sebelum dan sesudah mendapatkan program CSR di Kabupaten Berau.

Pemerataan pendapatan dapat dihitung berdasarkan Indeks Gini atau Gini Rasio. Indeks Gini adalah ukuran ketimpangan agregat yang angkanya berkisar antara nol (pemerataan sempurna) hingga satu (ketimpangan sempurna) yang selanjutnya diklasifikasikan sebagai berikut Apabila angka Gini Rasio lebih besar dari atau sama dengan 0 dan lebih kecil dari $0,4 \quad(0 \leq \mathrm{G}<0,4)$ maka dapat dikatakan bahwa tingkat ketimpangan rendah

Apabila angka Gini Rasio lebih besar dari atau sama dengan 0,4 dan lebih kecil dari $0,5(0,4 \leq \mathrm{G}<0,5)$ maka dapat dikatakan bahwa tingkat ketimpangan sedang. Apabila angka Gini Rasio lebih besar dari atau sama dengan 0,4 dan lebih kecil dari 1 $(0,5 \leq \mathrm{G}<1)$ maka dapat dikatakan bahwa tingkat ketimpangan tinggi.

\section{PEMBAHASAN}

Secara Umum pendapatan masyarakat sekitar tambang sebelum dan sesudah adanya program CSR perusahaan sangat beragam tergantung ada tidaknya sumber daya alam yang ada di wilayahnya. Dari sumber daya alam tersebut akan menarik iklim investasi yang kedepannya akan berpengaruh positif terhadap perekonomian kampungkampung di sekitarnya. Sebelum adanya perusahaan pertambangan masuk di daerah sekitar tambang, penghasilan rata-rata masyarakat dibawah Rp 250.000 perbulan. 
Pendapatan masyarakat tersebut sebagian besar hanya diperuntukan bagi pemenuhan kebutuhan seharihari. Sumber-sumber pendapatan masyarakat sekitar tambang umumnya bersumber dari sektor pertanian dan nelayan tradisional. Penghasilan masyarakat yang didapatkan hanya berorientasi pada pemenuhan kebutuhan sehari-hari. Adapun kelebihan pembiayaan / sisa dari kebutuhan pokok tersebut hanya sebagian kecil untuk dijual dimana hasilnya dibelanjakan kembali untuk tambahan beberapa faktor produksi baik pertanian maupun nelayan.

Setelah adanya beberapa perusahaan khususnya perusahaan pertambangan batubara masuk di wilayah sekitar tambang, sebagian besar masyarakat memperoleh beberapa nilai tambah, diantaranya terbukanya kesempatan mendapatkan pekerjaan, peluang berusaha dan adanya potensi untuk dapat memasarkan hasil-hasil pertanian dan perikanan. Secara umum kehadiran para pelaku usaha untuk melakukan investasi di daerah cukup besar memberikan kontribusi positif baik dari segi perekonomian yaitu peningkatan pendapatan maupun dari sisi sosial kemasyarakatan dimana kemajuan budaya masyarakatnya sangat kelihatan bila dibandingkan sebelum adanya perusahaan khususnya di wilayah sekitar tambang.

Hasil riset yang dilakukan PT Berau Coal yaitu pelaku usaha pertambangan batubara di Kabupaten Berau bersama forum komunikasi pemberdayaan lingkar tambang dan Biro Pusat Statistik dalam analisis sosial, ekonomi dan ketenagakerjaan, telah memetakan beberapa kegiatan atau tahapan yang harus dapat dipertimbangkan dalam kegiatan operasional perusahaan karena berpotensi terjadinya risiko sosial mulai dari tahapan kegiatan eksplorasi, kegiatan exploitasi, tahap konstruksi, operasi hingga kegiatan pasca tambang. Sementara dampak operasi perusahaan yang paling dominan adalah kegiatan blasting, pengeboran, Akses jalan dan aktifitas pengangkutan batubara melalui alur sungai (shiping activity).

Hasil riset yang dilakukan PT Berau Coal yaitu pelaku usaha pertambangan batubara di Kabupaten Berau bersama forum komunikasi pemberdayaan lingkar tambang dan 
Biro Pusat Statistik dalam analisis sosial, ekonomi dan ketenagakerjaan, telah memetakan beberapa kegiatan atau tahapan yang harus dapat dipertimbangkan dalam kegiatan operasional perusahaan karena berpotensi terjadinya risiko sosial mulai dari tahapan kegiatan eksplorasi, kegiatan exploitasi, tahap konstruksi, operasi hingga kegiatan pasca tambang. Sementara dampak operasi perusahaan yang paling dominan adalah kegiatan blasting, pengeboran, Akses jalan dan aktifitas pengangkutan batubara melalui alur sungai (shiping activity).

Dalam kaitannya dengan distribusi pendapatan masyarakat sekitar tambang yang termasuk kategori tinggi yaitu berkisar antara 0,65 sampai angka 0,79 , hal ini senada dengan pendapat Kuznets dalam Prapti (2006) mengemukakan bahwa suatu negara apabila masyarakatnya masih dalam keadaan miskin maka distribusi pendapatannya akan lebih merata dan apabila negara tersebut mulai mengadakan pembangunan maka distribusi pendapatan akan cenderung timpang, kemudian akan merata kembali apabila masyarakatnya sudah berada dalam hidup makmur. Redistribusi pendapatan dari pertumbuhan pada hakekatnya menganjurkan negara berkembang agar tidak hanya memusatkan perhatian pada pertumbuhan ekonomi (memperbesar kue pembangunan) namun juga mempertimbangkan bagaimana distribusi kue tersebut. Situasi ini bisa diwujudkan dangan kombinasi strategi seperti peningkatan kesempatan kerja, investasi sumber daya manusia, perhatian pada petani kecil, sektor informal dan pengusaha lemah atau syarat utamanya berorientasi pada sumber daya manusia.

$$
\text { Meratanya distribusi }
$$
pendapatan masyarakat saat masih berada taraf hidup miskin adalah karena status kepemilikan faktor produksi yang kecil, sementara pada taraf hidup dimana sudah ada pelaksanaan pembangunan distribusi pendapatan cenderung timpang adalah karena hasil pembangunan belum bisa dinikmati secara merata, disamping infrastruktur yang mendukung meningkatmya pendapatan masyarakat belum 
memadai. Suatu saat apabila hasilhasil pembangunan telah bisa dinikmati dan menyentuh seluruh lapisan masyarakat maka distribusi pendapatan akan kembali merata dengan kondisi taraf hidup yang lebih makmur.

Hasibuan dalam Rachman dan Supriyati, (2001) menyatakan bahwa dengan meningkatnya pembangunan ekonomi, kesenjangan pembagian pendapatan masyarakat juga meningkat, karena semakin cepat ekonomi berkembang maka orang mengharapkan hasil yang lebih tinggi dari pendidikannya. Pekerja dengan pendidikan dan keterampilan yang kreatif lebih rendah akan memperoleh upah yang rendah, hal ini yang membuat pembagian pendapatan dalam masyarakat semakin timpang.

Ketidakmerataan distribusi pendapatan di suatu negara umumnya disebabkan ketidakseimbangan regional dalam kepadatan penduduk, pendapatan per kapita dan pembangunan antara wilayah. Dalam pelaksanaannya cenderung bersifat sentralistik (top down) sehingga sangat jarang menyentuh langsung kepentingan masyarakat khususnya bagi masyarat yang tinggal jauh dari perkotaan. Oleh karena itu peranan swasta sangat diharapkan untuk dapat membantu pendistribusian pendapatan. Peran CSR diharapkan menjadi solusi, bermitra dengan pemerintah dan masyarakat di sekitar wilayah usaha perusahaan tersebut sebagaimana Ambadar (2008), yang menulis manfaat CSR yaitu dapat meningkatkan kualitas sumberdaya manusia, kelembagaan, tabungan, konsumsi dan investasi dari rumah tangga warga masyarakat.

\section{KESIMPULAN}

Berdasarkan analisis dan pembahasan yang telah diuraikan maka dapat ditarik beberapa kesimpulan sebagai berikut :

Berdasarkan hasil statistik uji t (test) pada semua Kampung yang menjadi obyek penelitian, didapatkan hasil bahwa $\mathrm{t}_{\text {hitung }}>\mathrm{t}_{\text {tabel }}$ maka Ha diterima dan Ho ditolak. Selanjutnya dapat dikatakan bahwa terdapat perbedaan pendapatan masyarakat Kampung sekitar tambang sebelum dan sesudah 
mendapatkan program CSR di Kabupaten Berau. Perbandingan pendapatan masyarakat sekitar tambang sebelum dan sesudah mendapatkan program CSR berbeda nyata, dimana semua kampung sekitar tambang terdapat pengaruh positif. Selisih nilai rata-rata peningkatan pendapatan pada setiap Kampung dari angka terbesar adalah Kampung Sambakungan yang kemudian secara berturut-turut diikuti oleh kampung Pagat Bukur, Kampung Tasuk, Kampung Tumbit, Kampung Birang, dan Kampung Maluang.

Dari data distribusi pendapatan masyarakat sekitar tambang sebelum dan sesudah mendapatkan program CSR terlihat bahwa telah terjadi ketimpangan distribusi pendapatan pendapatan masyarakat sekitar tambang sebelum mendapatkan program CSR dimana nilai Gini Rasio berkisar antara 0,65 sampai nilai Gini Rasio 1. Angka Gini Rasio terbesar sebelum adanya program CSR adalah pada kampung Sambakungan, Maluang dan Tasuk dengan nilai 1 , sedangkan angka Gini Rasio terkecil adalah pada kampung Pagat Bukur dan Tumbit dengan nilai 0,95. Angka Gini Rasio terbesar sesetelah adanya program CSR adalah pada kampung Tumbit dengan nilai 0,79 , sedangkan angka Gini Rasio terkecil adalah pada kampung Pagat Bukur dengan nilai 0,65 .

Secara keseluruhan, peneliti juga menyimpulkan bahwa peningkatan serta distribusi pendapatan yang tinggi yang terjadi pada beberapa Kampung sekitar tambang adalah karena keberhasilan perusahaan pertambangan dalam melaksanakan program CSR serta dukungan seluruh komponen masyarakat dan Pemerintah di daerah.

\section{DAFTAR PUSTAKA}

Anonim, 2011. Laporan Survei Analisis Ekonomi dan Ketenagakerjaan Daerah Lingkar Tambang Kabupaten Berau, Kerjasama BPS Kabupaten Berau, PT Berau Coal, dan Forum Komunikasi Pemberdayaan Lingkar Tambang, Berau

Budiono, 1998. Teori Pertumbuhan Ekonomi (Seri Sinopsis), Pengantar Ilmu Ekonomi, BPFE, Yogyakarta

Budimanta, Arif, Adi Prasetijo, dan Bambang Rudito. 2004. Corporate Social Responsibility "Alternatif 
Bagi Pembangunan

Indonesia”. ICSD.

Ife, Jime. 1995. Community Development: Creating Community Alternatives Vision, Analysis and Practice. Melbourne: Longman.

Jackie Ambadar. 2008. Corporate Social Responsibility (CSR) dalam Praktik di Indonesia. Wujud Kepedulian Dunia Usaha. Jakarta: PT Elex Media Komputindo.

Mubyarto, 1989. Pengantar Ekonomi Pertanian, Jakarta : LP3S

Prapti, Lulus NSS, 2006. Keterkaitan antara Pertumbuhan Ekonomi dan Distribusi Pendapatan, (Studi Kasus 35 Kabupaten / Kota Jawa Tengah tahun 2000- tahun 2004), Universitas Diponegoro, Semarang.
Riduwan, MBA. 2009. Pengantar Statistika Sosial. Penerbit Alfabeta, Bandung.

Supriyanto, Subejo. 2004. Harmonisasi Pemberdayaan Masyarakat Pedesaan dengan Pembangunan Berkelanjutan dalam http://subejo.staff.ugm. ac.id/wp-content/supriyantoekstensia.pdf.

Todaro, Michael P, Smith Stephen C. 2003. Pembangunan Ekonomi di Dunia Ketiga, Edisi Kedelapan. Penerbit Erlangga, Jakarta (terjemahan).

Wibisono, Yusuf. 2007. Membedah Konsep dan Aplikasi CSR "Membedah Konsep dan Aplikasi CSR (Corporate Social Responsibility. Gresik: Fascho Publishing. 